\title{
Frequency of D222G haemagglutinin mutant of pandemic (H1N1) pdm09 influenza virus in Tunisia between 2009 and 2011
}

Awatef El Moussi', Mohamed Ali Ben Hadj Kacem', Francisco Pozo², Juan Ledesma ${ }^{2 *}$, Maria Teresa Cuevas², Inmaculada Casas $^{2}$ and Amine Slim ${ }^{1}$

\begin{abstract}
Background: The novel pandemic A (H1N1) pdm09 virus was first identified in Mexico in April 2009 and since then it spread worldwide over a short period of time. Although the virus infection is generally associated with mild disease and a relatively low mortality, it is projected that mutations in specific regions of the viral genome, especially within the receptor binding domain of the haemagglutinin (HA) protein could result in more virulent virus stains, leading to a more severe pathogenicity.
\end{abstract}

Methods: To monitor the genetic polymorphisms at position 222 of Haemagglutinin of influenza A(H1N1)pdm09 viruses from both outpatients with mild influenza and individuals with severe disease requiring hospitalization, during 2009-2010 and 2010-2011 seasons, a sequence-based genotypic assessment of viral populations to understand the prevalence of D222G mutation.

Results: The D222G was identified in clinical specimens from 3 out of 42 cases analyzed in Tunisia with severe outcome (7\%). Interestingly, in one fatal case out of four viruses taken from fatal cases studied (25\%). Also this mutation was found in one mild case out of 8 mild cases studied (0.1\%). D222E substitution was found in virus taken from one patient with severe clinical syndrome (2\%) out of 42 severe cases analyzed and E374K substitution was found in two severe cases (4\%) out of 42 severe cases studied.

Conclusions: A specific mutation in the viral haemagglutinin (D222G) was found in fatal, severe and mild case. Further virological, clinical and epidemiological investigations are needed to ascertain the role of this and other mutations that may alter the virulence and transmissibility of the pandemic influenza A (H1N1)pdm09.

Virtual Slides: The virtual slide(s) for this article can be found here: http://www.diagnosticpathology.diagnomx.eu/ vs/1027334947811255

Keywords: D222G substitution, Haemagglutinin, Influenza A(H1N1)pdm09 virus, Pandemic, Severe respiratory infection

\section{Introduction}

In April 2009, a novel swine-derived influenza A(H1N1) pdm09 emerged and spread rapidly around the world $[1,2]$, causing the World Health Organization to declare a pandemic in June. Since the first appearance of influenza A(H1N1)pdm09, one particular amino acid substitution \{aspartic acid to glycine at position 222 (D222G)\} (225 in

\footnotetext{
*Correspondence: jledesmam@yahoo.es

${ }^{2}$ National Influenza Centre-Madrid, Influenza and Respiratory Viruses

Laboratory, Instituto de Salud Carlos III, Madrid, Spain

Full list of author information is available at the end of the article
}

H3 numbering) within the hemagglutinin (HA) molecule has appeared sporadically in 20 countries, including Norway, Mexico, Ukraine and the USA [3-5]. The D222G substitution is known to cause a shift from $\alpha 2,6-\mathrm{SA}$ receptor specificity to mixed $\alpha 2,3 / \alpha 2,6$-sialic acid receptor specificity [6,7]. It is noteworthy that is highly conserved among avian viruses [8]. Previously, $\alpha 2,3$-specific avian viruses have been isolated from patients during the initial phases of the pandemics of 1957 and 1968, and avian HA in humans has been shown to be selected for increased affinity for the $\alpha 2,6$ receptor [8]. Also, the substitution was

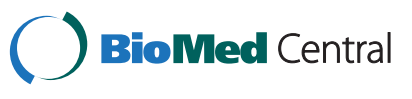


present in the Spanish Flu outbreak of 1918 [9]; however, the existence and transmissibility of influenza $\mathrm{A}(\mathrm{H} 1 \mathrm{~N} 1)$ pdm09 $\alpha 2,3-S A$ specific viruses remain unclear. To identify whether $\alpha 2,3-S A$ specific viruses, which replicate well in swine, were spread during the early phase of the pandemic and whether $\alpha 2,3-S A$ specific viruses are easily transmitted, the nucleotide sequences of the HA receptor binding site of influenza $\mathrm{A}(\mathrm{H} 1 \mathrm{N1}) \mathrm{pdm} 09$ in clinical specimens were determined in this study.

In an attempt to understand the relevance of HA D222G substitution among influenza A(H1N1)pdm09 causing infections in Tunisia, HA gene sequences from respiratory specimens of severe and non-severe cases were examined. In addition to the D222G substitution, we focused on another substitution \{glutamic acid 374 to lysine acid (E374K)\}, mutation located at the stalk of HA2 in the cavity where the fusion domain of mature HA molecules might have an impact on the antigenicity or neutralization activity of influenza A(H1N1)pdm09 [10-12].

\section{Material and methods}

Nasopharyngeal or throat swab specimens from influenza patients are received directly from sentinel primary care physicians participating in virological surveillance schemes in the community. Samples are also received from community, hospitalised and fatal cases are forwarded to the Tunisia National Influenza Centre for diagnostic and further characterisation. A total of 7350 specimens from influenza patients were collected in Tunisia during 20092010 season and 894 specimens during 2010-2011 season.

The samples used in this study were taken from 50 patients including 42 respiratory specimens from severe (patients hospitalized with severe pneumonia and severe acute respiratory syndrome) and fatal cases, as well as from 8 cases with mild clinical outcomes. Mild cases presented with at least one of the following influenzalike illness symptoms: fever of at least $38^{\circ} \mathrm{C}$, cough, rhinorrhea, headache, or abdominal symptoms (i.e., diarrhea and vomiting).

Viral RNA was extracted from respiratory samples (Oro-pharyngeal and nasopharyngeal swabs) using commercially available QIAamp Viral RNA Mini Kit QIAGEN as per manufacturer's instructions. For initial detection of Influenza A virus, amplification of matrix protein $(\mathrm{M})$ gene was carried by real time RT-PCR CDC protocol [13]. For subtyping of Influenza A positive samples, the HA gene (segment 4) of influenza $\mathrm{A}(\mathrm{H} 1 \mathrm{~N} 1) \mathrm{pdm} 09$ viruses were analyzed by specific real-time PCR using "Influenza virus A 1 Real Time RT-PCR Kit" (Shanghai ZJ Bio-Tech Co. Ltd). In order to identify the Changes in HA amino acid diversity in individual cases, genetic characterisation is performed by targeted haemagglutinin (HA) sequence analysis and/or partial genome (931 nucleotide residues) sequencing for a subset of isolates. All viruses analyzed were amplified and sequenced according to the protocol of National Influenza Centre Madrid [14]. Primers PHA1+ (5'-GGGGTTAGCAAAAGCAGGRG-3') and PHA1- (5'CAWCCRKCIAYCAKICCWKICCAICC-3') were used for RT-PCR and H1 + SSEQB (5'-AAYAAYTCIACYGACAC TG-3') and H1-ASEQ (5'-CCCTCAATRAAACCRGCA AT-3') for nested PCR.

The sequences were analyzed using the maximum composite likelihood method and the MEGA version 4.0 software package with 500 bootstrap replicates [15]. Nucleotide sequence accession numbers: The nucleotide sequences of HA determined in this study can be found in GenBank databases under the indicated accession numbers JN037697 to JN037779 (http://WWW.ncbi.nih. gov/genomes/FLU/SwineFlu.html).

\section{Ethical approval}

The ethical aspects of this study were approved by Charles Nicolle's Hospital ethic committee.

\section{Results}

During the pandemic year, a total of 3836 out of 7350 respiratory specimens with ILI coming from the sentinel physicians network were positive for influenza $\mathrm{A}(\mathrm{H} 1 \mathrm{~N} 1)$ pdm (95\%). In 2010-2011 season, 146 out of 894 of the cases were positive for influenza $\mathrm{A}(\mathrm{H} 1 \mathrm{~N} 1) \mathrm{pdm} 09$ (70\%). Here we report the occurrence of an amino acid substitution, aspartic acid to glycine in position 222 (D222G) in the HA subunit of the viral haemagglutinin, in clinical specimens from 3 out of 42 cases analyzed in Tunisia with severe outcome (7\%). Interestingly, in one fatal case out of four viruses taken from fatal cases studied (25\%). This patient died after 3 days, suffering of severe respiratory symptoms of flu. Autopsy revealed pulmonary oedema, large mucosis secretions but no cardiac inflammation (Table 1). Also this mutation was found in one mild case out of 8 mild cases studied (0.1\%). Moreover, $\mathrm{D} 222 \mathrm{E}$ was found in one out of 50 viruses studied. This mutation was found in virus taken from one patient with severe clinical syndrome out of 42 severe cases studied (2\%). E374K substitution was found in two severe cases (4\%). This analysis of HA also showed frequent substitutions in other positions. P83S and S203T were detected in $94 \%$ of Tunisian viruses studied.

\section{Discussion}

Genetic analysis of HA of influenza A (H1N1)pdm09 virus showed that this virus was a reassortant containing gene segments from ancestor viruses of human, swine and avian sources. Hence, Polymorphism at position 222 within the haemagglutinin (HA) molecule may have remarkable impact on viral host range, replication, and pathogenicity. It is worth noting that although the 
Table 1 Characteristics of patients according to the outcome of the infections and molecular analysis

\begin{tabular}{|c|c|c|c|c|c|c|}
\hline $\begin{array}{l}\text { Virus strains of influenza } \\
\text { A(H1N1)pdm09 }\end{array}$ & $\begin{array}{l}\text { Date of } \\
\text { sampling }\end{array}$ & $\begin{array}{l}\text { GenBank accession } \\
\text { number }\end{array}$ & Mutation & Age & Sex & Clinical information \\
\hline A/Tunisia/20043/2009 & $12 / 12 / 2009$ & JN037731 & K374E & 33 & Male & Severe pneumonia \\
\hline A/Tunisia/20112/2009 & $14 / 12 / 2009$ & JN037733 & $\mathrm{D} 222 \mathrm{E}$ & 43 & Male & $\begin{array}{l}\text { Severe pneumonia with acute respiratory } \\
\text { syndrome }\end{array}$ \\
\hline A/Tunisia/1064/2010 & 18/01/2010 & HM590676 & D222G & 47 & Male & Severe pneumonia and death \\
\hline A/Tunisia/197/2011 & $04 / 01 / 2011$ & CY080589 & K374E & 46 & Female & Severe pneumonia \\
\hline A/Tunisia/1411/2011 & $7 / 02 / 2011$ & JN037741 & D222G & 15 & Male & Mild case \\
\hline A/Tunisia/1701/2011 & 10/02/2011 & JN037743 & D222G & 45 & Male & Severe pneumonia requiring intensive care \\
\hline
\end{tabular}

$\mathrm{D}$, aspartic acid; G, glycine; $\mathrm{E}$, glutamic acid; $\mathrm{K}$, lysine.

Asp222Gly mutation currently has not been associated with severe pandemic in humans.

An association between D222G and severity was initially proposed by Kilander et al. (2010) [16] and, since then, different studies in several countries [17] have found the D222G substitution to be more frequently associated with patients with severe pandemic influenza than in nonsevere control cases. A recent study supported a role for this mutation in allowing the virus access to deeper lung tissue [18]. Hese unusual viral attributes suggested that this new virus may possess some virulence characteristics similar to the highly pathogenic H5N1 or the 1918 pandemic influenza viruses.

This study used a conventional sequencing approach to analyze $50 \mathrm{H} 1 \mathrm{~N} 1 \mathrm{pdm}$ samples obtained from 2009 to 2011. Viruses with D222G substitution in HA protein have appeared sporadically and spontaneously in Tunisia since July 2009 [19]. Although, 7\% of them, found in severe cases in the present study, had the D222G substitution. This percentage is comparable to that found in Italy (4\%) [5], in United Kingdom (6\%) [17], in France (8\%) [20] or in Spain (5\%) [14], and lower than that published in Norway (18\%) [16], and in Hong Kong (17.4\%) [21]. These differences with the Norwegian and Chinese study might be due to the reduced number of severe cases analyzed in that country. In Tunisia, this mutation was observed in circulating virus obtained from severe cases [19] and also from mild cases. The frequency of D222G substitution is higher in severe cases than mild cases. Although most of studies demonstrated the presence of D222G substitution in severe cases, it was also reported in mild cases $[5,22]$. Therefore, the number of mild cases would need to be larger to determine whether mutant viruses are indeed circulating at a very low frequency also in non-severe cases.

The $222 \mathrm{G} / \mathrm{E}$ polymorphisms in the haemagglutinin (HA) gene of influenza $\mathrm{A}(\mathrm{H} 1 \mathrm{N1})$ pdm09 virus have been associated with cases of mild to severe illness from different countries or geographical areas [23]. Many retrospective analyses have found that cases bearing the D222G mutation were more likely to be associated with severe pneumonia, admission to intensive care facilities, and death [24]. The majority of studies have reported that presence of D222G is sufficient to enhance virus replication and lethality in mouse models, with this effect ranging from modest to pronounced [25,26]. Moreover, D222G substitution had been present in the Tunisian virus strain since pandemic season and throughout 2010-2011 season. Other groups have not observed substantial differences between wild-type and D222G viruses in mouse or ferret models [6], indicating the need for further investigation into the role of D222G in virulence of influenza A (H1N1)pdm09. The D222E was detected with less frequency than the D222G and only found in severe case patient. Despite the available virological, epidemiological and clinical information, the D222E substitution could confer more severity to the disease. The clinical significance of this mutation is still unclear [27]. All above studies demonstrated that polymorphism of the HA protein, especially within the receptor binding domain, play a critical role in the binding preference and pathogenicity of influenza $\mathrm{A}(\mathrm{H} 1 \mathrm{~N} 1)$ pdm09 virus. Further study is warranted to elucidate the intriguing relationship between D222G substitution and severe disease.

\section{Conclusion}

Whether the selection of the D222G mutation is a cause or a consequence of more severe lower respiratory tract infection is still to be resolved. It is evident, however, that its emergence is likely to exacerbate the severity of disease. The altered receptor specificity and distinctive cell tropism of the D222G mutants of influenza A(H1N1)pdm09 are hallmarks of a more dangerous pathogen, emphasizing the importance of close monitoring of the evolution of these viruses. Influenza $\mathrm{A}(\mathrm{H} 1 \mathrm{~N} 1) \mathrm{pdm} 09$ variants with $222 \mathrm{G} /$ E polymorphisms showed increased clinical virulence, and detection of such mutants in the next epidemics is mandatory for better management of ILI in individual patients as well as for surveillance purposes especially in African countries. 


\section{Consent}

For all participants, respiratory samples were collected after informed consent, under the supervision of local sanitary authorities.

\section{Abbreviations \\ HA: Haemagglutinin; SA a2,6: Sialic acids a2,6; SA a2,3: Sialic acids a2,3: ILI: Influenza-like illness.}

\section{Competing interests}

None of the authors has a financial or personal conflict of interest related to this study.

\section{Authors' contributions}

AEM: proposed the idea, analyzed and interpreted the data presented in the paper. Also she wrote the manuscript; FP and $J$ : participated in the data analysis and interpretation. Also they revised the manuscript; MTC and IC: revised the manuscript; $A S$ and MHK: revised the manuscript and save final approval of the version to be published. All authors read and approved the final manuscript.

\section{Acknowledgements}

We are grateful to Ines Laaibi in the National Influenza Centre-Tunis; Mónica Gónzalez-Esguevillas, Nieves Cruz, Ana Calderón, Noelia Reyes, Manuela Lopez-Valero, Mar Molinero and Silvia Moreno in the National Influenza Centre Madrid for technical support.

\section{Author details}

${ }^{1}$ National Influenza Centre-Tunis, Unit Virology, Microbiology Laboratory, Charles Nicolle's Hospital, Tunis, Tunisia. ${ }^{2}$ National Influenza Centre-Madrid Influenza and Respiratory Viruses Laboratory, Instituto de Salud Carlos III, Madrid, Spain.

\section{Received: 24 September 2012 Accepted: 10 March 2013}

Published: 31 July 2013

\section{References}

1. Miller MA, Viboud C, Balinska M, Simonsen L: The signature features of influenza pandemics-implications for policy. N Engl J Med 2009, 360(25):2595-2598.

2. Neumann G, Noda T, Kawaoka Y: Emergence and pandemic potential of swine-origin H1N1 influenza virus. Nature 2009, 459(7249):931-939.

3. Ikonen N, Haanpaa M, Ronkko E, Lyytikainen O, Kuusi M, Ruutu P, KallioKokko H, Mannonen L, Lappalainen M, Ziegler T, Julkunen I: Genetic diversity of the 2009 pandemic influenza $\mathrm{A}(\mathrm{H} 1 \mathrm{~N} 1)$ viruses in Finland. PLoS One 2010, 5(10):e13329.

4. Kuroda M, Katano H, Nakajima N, Tobiume M, Ainai A, Sekizuka T, Hasegawa H, Tashiro M, Sasaki Y, Arakawa Y, Hata S, Watanabe M, Sata T Characterization of quasispecies of pandemic 2009 influenza $A$ virus (A/H1N1/2009) by de novo sequencing using a next-generation DNA sequencer. PLoS One 2010, 5(4):e10256.

5. Puzelli S, Facchini M, Spagnolo D, De Marco MA, Calzoletti L, Zanetti A Fumagalli R, Tanzi ML, Cassone A, Rezza G, Donatelli I: Surveillance Group for Pandemic A H1N1 2009 Influenza Virus in Italy: Transmission of hemagglutinin D222G mutant strain of pandemic (H1N1) 2009 virus. Emerg Infect Dis 2010, 16(5):863-865.

6. Chutinimitkul S, Herfst S, Steel J, Lowen AC, Ye J, van Riel D, Schrauwen EJ, Bestebroer TM, Koel B, Burke DF, Sutherland-Cash KH, Whittleston CS, Russell CA, Wales DJ, Smith DJ, Jonges M, Meijer A, Koopmans M, Rimmelzwaan GF, Kuiken T, Osterhaus AD, García-Sastre A, Perez DR, Fouchier RA: Virulence-associated substitution D222G in the hemagglutinin of 2009 pandemic influenza $A(H 1 N 1)$ virus affects receptor binding. J Virol 2010, 84(22):11802-11813.

7. Liu Y, Childs RA, Matrosovich T, Wharton S, Palma AS, Chai W, Daniels R, Gregory V, Uhlendorff J, Kiso M, Klenk HD, Hay A, Feizi T, Matrosovich M: Altered receptor specificity and cell tropism of D222G hemagglutinin mutants isolated from fatal cases of pandemic $A(H 1 N 1) 2009$ influenza virus. J Virol 2010, 84(22):12069-12074.

8. Matrosovich M, Tuzikov A, Bovin N, Gambaryan A, Klimov A, Castrucci MR, Donatelli I, Kawaoka Y: Early alterations of the receptor-binding properties of $\mathrm{H} 1, \mathrm{H} 2$, and $\mathrm{H} 3$ avian influenza virus hemagglutinins after their introduction into mammals. J Virol 2000, 74(18):8502-8512.

9. Tumpey TM, Maines TR, Van Hoeven N, Glaser L, Solorzano A, Pappas C, Cox NJ, Swayne DE, Palese P, Katz JM, García-Sastre A: A two-amino acid change in the hemagglutinin of the 1918 influenza virus abolishes transmission. Science 2007, 315(5812):655-659.

10. Kao CL, Chan TC, Tsai CH, Chu KY, Chuang SF, Lee CC, Li ZR, Wu KW, Chang $L Y$, Shen YH, Huang LM, Lee PI, Yang C, Compans R, Rouse BT, King CC: Emerged $\mathrm{HA}$ and NA mutants of the pandemic influenza H1N1 viruses with increasing epidemiological significance in Taipei and Kaohsiung, Taiwan, 2009-10. PLoS One 2012, 7(2):e31162.

11. Ekiert DC, Bhabha G, Elsliger MA, Friesen RH, Jongeneelen M, Throsby $M$ Goudsmit J, Wilson IA: Antibody recognition of a highly conserved influenza virus epitope. Science 2009, 324(5924):246-51.

12. Sui J, Hwang WC, Perez S, Wei G, Aird D, Chen LM, Santelli E, Stec B, Cadwell G, Ali M, Wan H, Murakami A, Yammanuru A, Han T, Cox NJ, Bankston LA, Donis RO, Liddington RC, Marasco WA: Structural and functional bases for broad-spectrum neutralization of avian and human influenza A viruses. Nat Struct Mol Biol 2009, 16(3):265-273.

13. World Health Organization: CDC protocol of realtime RTPCR for swine influenza A(H1N1)2009. 2009. http://www.who.int/csr/resources/publications/ swineflu/CDCrealtimeRTPCRprotocol_20090428.pdf.

14. Ledesma J, Pozo F, Ruiz MP, Navarro JM, Piñeiro L, Montes M, Castro SP, Fernández JS, Costa JG, Fernández M, Galán JC, Cuevas MT, Casas I, Breña PP: Spanish Influenza Surveillance System (SISS): Substitutions in position 222 of haemagglutinin of pandemic influenza A (H1N1)2009 viruses in Spain. J Clin Virol 2011, 51(1):75-8.

15. Tamura K, Dudley J, Nei M, Kumar S, MEGA4: Molecular Evolutionary Genetics Analysis (MEGA) software version 4.0. Mol Biol Evol 2007, 24(8):1596-1599.

16. Kilander A, Rykkvin R, Dudman SG, Hungnes O: Observed association between the HA1 mutation D222G in the 2009 pandemic influenza A (H1N1) virus and severe clinical outcome, Norway 2009-2010. Euro Surveill 2010, 15(9):19498.

17. Miller RR, MacLean AR, Gunson RN, Carman WF: Occurrence of haemagglutinin mutation $D 222 \mathrm{G}$ in pandemic influenza $A(\mathrm{H} 1 \mathrm{~N} 1)$ infected patients in the West of Scotland, United Kingdom, 2009-10. Euro Surveill 2010, 15(16):19546.

18. Zhang Y, Sun H, Fan L, Ma Y, Sun Y, Pu J, Yang J, Qiao J, Ma G, Liu J: Acute respiratory distress syndrome Induced by a swine $2009 \mathrm{H} 1 \mathrm{~N} 1$ variant in mice. Plos One 2012, 7(1):e29347.

19. El Moussi A, Ledesma J, Ben Hadj Kacem MA, Pozo F, Cuevas MT, Hamdoun M, Casas I, Perez-Breña P, Slim A: Haemagglutinin D222G mutation found in a fatal case of pandemic (H1N1) flu in Tunisia. Arch Virol 2012, 157(9):1813-4.

20. Malato L, Llavador V, Marmier E, Youssef J, Balick Weber C, Rozé H, Bessede E, Fleury HJ: Pandemic influenza A(H1N1)2009: molecular characterisation and duration of viral shedding in intensive care patients in Bordeaux south-west France, May 2009 to January 2010. Euro Surveill 2011, 16(4):19776.

21. Chan PK, Lee N, Joynt GM, Choi KW, Cheung JL, Yeung AC, Lam P, Wong R, Leung BW, So HY, Lam WY, Hui DC: Clinical and virological course of infection with haemagglutinin D222G mutant strain of 2009 pandemic influenza A (H1N1) virus. J Clin Virol 2011, 50(4):320-4

22. Melidou A, Gioula G, Exindari M, Chatzidimitriou D, Diza E, Malisiovas N: Molecular and phylogenetic analysis of the haemagglutinin gene of pandemic influenza H1N1 2009 viruses associated with severe and fatal infections. Virus Res 2010, 151(2):192-9.

23. World Health Organization: Preliminary review of D222G amino acid substitution in the haemagglutinin of pandemic influenza $A(H 1 N 1) 2009$ viruses. Wkly Epidemiol Rec 2010, 85(4):21-2.

24. Baldanti F, Campanini G, Piralla A, Rovida F, Braschi A, Mojoli F, lotti G, Belliato M, Conaldi PG, Arcadipane A, Pariani E, Zanetti A, Minoli L, Emmi V: Severe outcome of influenza A/H1N1/09v infection associated with $222 \mathrm{G} / \mathrm{N}$ polymorphisms in the haemagglutinin: a multicentre study. Clin Microbiol Infect 2011, 17(8):1166-9.

25. Xu L, Bao L, Lv Q, Deng W, Ma Y, Li F, Zhan L, Zhu H, Ma C, Qin C: A singleamino-acid substitution in the HA protein changes the replication and pathogenicity of the 2009 pandemic $A(H 1 N 1)$ influenza viruses in vitro and in vivo. Virol J 2010, 7:325.

26. Chan KH, Zhang AJ, To KK, Chan CC, Poon VK, Guo K, Ng F, Zhang QW, Leung VH, Cheung AN, Lau CC, Woo PC, Tse H, Wu W, Chen H, Zheng BJ, 
Yuen KY: Wild type and mutant 2009 pandemic influenza $A(H 1 N 1)$ viruses cause more severe disease and higher mortality in pregnant BALB/c mice. PLoS One 2010, 5(10):e13757.

27. Grant MPY, Puzelli S, Facchini M, Spagnolo D, De Marco MA, Calzoletti L, Zanetti A, Fumagalli R, Tanzi ML, Cassone A, Rezza G, Donatelli I:

Surveillance Group for Pandemic A H1N1 2009 Influenza Virus in Italy: Transmission of hemagglutinin D222G mutant strain of pandemic (H1N1) 2009 virus. Emerg Infect Dis 2010, 16(5):863-865.

doi:10.1186/1746-1596-8-124

Cite this article as: El Moussi et al:: Frequency of D222G haemagglutinin mutant of pandemic (H1N1) pdm09 influenza virus in Tunisia between 2009 and 2011. Diagnostic Pathology 2013 8:124.

\section{Submit your next manuscript to BioMed Central and take full advantage of:}

- Convenient online submission

- Thorough peer review

- No space constraints or color figure charges

- Immediate publication on acceptance

- Inclusion in PubMed, CAS, Scopus and Google Scholar

- Research which is freely available for redistribution 